\title{
Macro-microscopical aspects of the buffalo (Bubalus bubalis Linnaeus, 1758) pineal gland
}

\author{
Ana Flávia de Carvalho ${ }^{1 *}$ \\ Carlos Eduardo Ambrósio ${ }^{2}$ \\ Maria Angélica Miglino² \\ Celina Almeida Furlanetto Mançanares ${ }^{1}$ \\ Francisco Javier Hernandez Blazquez ${ }^{2}$ \\ ${ }^{1}$ Centro Universitário da Fundação de Ensino Octávio Bastos \\ Faculdade de Medicina Veterinária \\ Av. Octávio Bastos s/n, Campus II, CEP 13 870-000, São João da Boa Vista - SP, Brazil \\ ${ }^{2}$ Universidade de São Paulo, Faculdade de Medicina Veterinária \\ Departamento de Cirurgia, Anatomia dos Animais Domésticos e Silvestres \\ Av. Orlando Marques de Paiva, 87, CEP 05508-270, São Paulo - SP, Brazil \\ *Author for correspondence \\ anaflaviac@uol.com.br
}

Submetido em 07/05/2008

Aceito para publicação em 20/11/2008

\begin{abstract}
Gross and microscopical aspects of the buffalo pineal gland were described in seasonal parturition animals, since this gland is responsible for melatonin secretion which acts upon the hypothalamus-hypophysis reproductive axis feedback system. (Hafez, 1995). For the present study, 11 cross-bred buffaloes, predominantly of the Mediterranean breed, from the Pirassununga Campus - USP (University of São Paulo), were killed in different photoperiods in the slaughterhouse. The pineal glands were obtained, fixed, weighed, measured, photographed, processed, cut into sections and stained. All glands demonstrated the same global shape, with a mean length of 8.82 $\pm 1.07 \mathrm{~mm}$ and a width of $7.91 \pm 0.83 \mathrm{~mm}$, and a stem length of $5.50 \pm 4.18 \mathrm{~mm}$. The stems had a microscopically visible lumen. The mean gland weight was $251.45 \pm 83.1 \mathrm{mg}$. The buffalo pineal gland presented right and left lobes of different sizes. Microscopically, they were surrounded by a connective tissue layer with blood vessels infiltrating into the glandular parenchyma, which became separated into glial cell lobules. A great number of the pinealocytes were arranged in irregular strings, and cells from the connective tissue could be observed in the glandular parenchyma. We conclude that the buffalo pineal gland is similar to that of pineal cows and that it does not show morphologic alterations during different photoperiods of the year.
\end{abstract}

Key words: pineal gland, buffalo, pinealocytes

\section{Resumo}

Aspectos macro e microscópicos da glândula pineal de búfalos (Bubalus bubalis Linnaeus, 1758). Os aspectos macro e microscópicos da glândula pineal de búfalos adultos foram descritos em animais que apresentavam partos sazonais, sabendo-se que esta glândula é responsável pela secreção de melatonina atuando 
no eixo hipotálamo hipofisário e sazonalidade reprodutiva (Hafez, 1995). Para o presente estudo, 11 búfalos mestiços, predominantemente da raça Mediterrâneo, proveniente do Campus da USP (Universidade de São Paulo) Pirassununga foram mortos em diferentes fotoperíodos em abatedouro. As glândulas pineais foram coletadas, fixadas, pesadas, medidas, fotografadas, processadas, cortadas e coradas. Todas as glândulas apresentaram formato globoso, com média de comprimento de $8,82 \pm 1,07 \mathrm{~mm}$ e largura de 7,91 $\pm 0,83 \mathrm{~mm}$ e comprimento de haste de $5,50 \pm 4,18 \mathrm{~mm}$. A haste apresentava lume microscopicamente visível. A média de peso foi $251,45 \pm 83,1 \mathrm{mg}$. A glândula pineal do búfalo possuía dois lobos (direito e esquerdo) e diferentes tamanhos. Microscopicamente eram circundadas por tecido conjuntivo com vasos que dividia a glândula em lóbulos de células gliais. Um grande número de pinealócitos estava arranjado de maneira irregular, e células do tecido conjuntivo puderam ser observadas no parênquima glandular. Concluímos que a glândula pineal do búfalo é semelhante à dos bovinos e não apresenta alterações morfológicas durante diferentes fotoperíodos do ano.

Unitermos: glândula pineal, búfalo, pinealócitos

\section{Introduction}

The buffaloes, like bovines, are polyestrous and breed during the entire year in Brazil. The seasonal patterns of births reported in various countries are attributed to the environmental temperature, to photoperiods, and to the alimental supply. Buffaloes that give birth in the summer or the autumn resume their ovarian cycle earlier than those that breed in the winter or spring (Ahmed et al., 1981). The length of the day and colder atmospheric temperatures probably favor the cycle. During the summer, when atmospheric temperatures and the photoperiod are maximal, the levels of prolactin are higher (Kaker et al., 1982) and the levels of plasma progesterone are lower (Rao and Pandey, 1982). High atmospheric temperatures may also contribute to this seasonality by depressing the masculine libido (Hafez, 1995). An intricate endocrine system, which involves the pineal gland, causes this seasonality in polyoestric animals.

The anatomic localization of the gland in the brain was similar to that described in other mammals, including the ruminants identified by Vollrath (1981). Macroscopically, it is divided into two lobes, left and right, and it is found among the rostral colicules in the median fissure of the brain, possessing an insertion in the habenular commissura, which communicates directly with the third ventricles. Arterial irrigation occurs via the pineal network, where the dorsal position of the gland is covered with a tangled vascular complex which penetrates the gland, dividing it, macroscopically, into two lobes, left and right.
Vollrath (1979) classified ruminant pineals that are restricted to the vicinity of the third ventricle as type A and reported that the animal's metabolic weight bears no relationship with the gland weight.

Melatonin, which is synthesized at night by the pineal gland, is present in the cerebrospinal fluid (CSF). CSF melatonin concentrations are higher near the pineal gland than in the anterior part of the third ventricle, and decrease markedly (80\%) after sealing off the pineal recess. Moreover, ultrastructure and permeability analyses of the pineal-CSF interface showed that melatonin could reach the CSF either via delivery in situ by protruding pinealocytes that make direct contact with the CSF or via extracellular secretion and interstitial fluid draining into the ventricular lumen. These data indicate that melatonin in the CSF probably originates from a few pinealocytes of the basal part of the pineal gland neighboring the pineal recess. Melatonin carried to the brain by the blood appears to be able to mediate the effects of photoperiod on reproduction, but it is unclear whether melatonin in the CSF may fine-tune this response in terms of either timing or amplitude. It is critical to determine which pathway, blood or CSF, allows melatonin to reach its central targets more efficiently (Tricoire et al., 2003).

In the cow, it is from 30 days of gestation that the first glandular outline becomes differentiated from the diencephalic ependyma of the third ventricle. This differentiation includes the phenomena of proliferation and multiplication of the ependymal cells that form the epithelium of the pineal outline in development. At 82 days of intrauterine life, in the interior of the 
pineal parenchyma, your witnessed some incipient pseudoglandular structures that at 135 days were well differentiated (Regodón and Roncero, 2005).

Regodón et al. (2006) reported at 200 days, of gestation in the interior of the pineal parenchyma, some morphologically rounded cells with oval euchromatic nuclei and a well-differentiated nucleolus has observed and blood vessels, at 240 days of gestation, showed wellformed walls where the endothelial cells stood out.

In ungulates and primates, pinealocytes constantly synthesize arylalkylamine $\mathrm{N}$-acetyltransferase, AANAT, protein from continually available AANAT mRNA. During the day - in the absence of noradrenergic stimulation - the protein is immediately destroyed by proteasomal proteolysis. At nighttime, elevated cAMP levels cause phosphorylation of AANAT by protein kinase A. This posttranslational modification leads to the interaction of phosphorylated AANAT with regulatory 14-3-3 proteins, which protect AANAT from degradation. Increases in AANAT protein are paralleled by increases in enzymatic activity. Stimulation of the cAMP/protein kinase A pathway may also activate pineal gene expression. In rodents, transcriptional activation of the AANAT gene is the primary mechanism for the induction of melatonin biosynthesis and results in marked day/night fluctuations in AANAT mRNA. It involves protein kinase A-dependent phosphorylation of the transcription factor cyclic AMP response elementbinding protein (CREB) and binding of phosphorylated CREB in the promoter region of the AANAT gene. A common neuroendocrine principle, the nocturnal rise in melatonin, is controlled by strikingly diverse regulatory mechanisms. This diversity has emerged in the course of evolution and reflects the high adaptive plasticity of the melatonin-generating pineal organ (Schomerus and Korf, 2005).

The buffalo of the Pirassununga region, São Paulo, Brazil, demonstrate reproductive seasonality, which occurs in $89.2 \%$ of buffaloes in the first half of the year with larger peaks in the first trimester. The heifers do not demonstrate seasonality, and therefore fit into the parturitions of the second half of the year. The object of this work was to study the macro-microscopical aspects of the pineal gland of the buffalo, with the aim of improving the understanding of the physiological factors that cause seasonality in these animals. This knowledge may contribute to an increase in the productivity of the buffalo flock, with the adoption of adequate reproduction handling and the creation of a specific mounting season and a consequent increase in the production of milk in desired periods.

\section{Material and Methods}

The 11 animals used in this study were obtained from the campus of Pirassununga - FMVZ-USP, latitude of $21^{\circ} 56^{\prime} 46^{\prime}$, , longitude $47^{\circ} 25^{\prime} 33^{\prime \prime}$, Brazil, and divided into three groups according to weight to verify the variations between the weights of the glands and the metabolic weights of the animals in different photoperiods (short-autumn/winter and long-spring/ summer). This procedure was used to observe the morphological cellular differences in accordance with photoperiod and seasonality. Brains were immediately removed and fixed in a $4 \%$ paraformaldehyde solution in PBS (Dulbecco's phosphate buffer saline, Gibco, USA) and were later transported from the slaughterhouse to the laboratory for dissection and removal of the pineal gland.

The pineal of each animal was photographed, measured with a paquimeter and weighed on an analytical balance, before being post-fixed in McDowell's liquid (McDowell and Trump, 1976). Glands were then immersed in paraffin and historesin (Jung-historesin - lot $\mathrm{n}^{\circ} 70-2218-500 /$ Leica), preserving the divided portions in situ. The material was sectioned with a Leica 2033 microtome and different stains were used in order to observe the architecture and volumetric proportion of the pinealocytes of the gland. Stains used were: picrosirius (Junqueira et al., 1979), silver methanamine periodic acid, Toluidine blue (Gerrits, 1983), hematoxilin and eosin (Tolosa et al., 2003), PAS - periodic acid reactive to Schiff with Harris' hematoxilin base (Lillie and Fulmer, 1976). The statistical analyses were performed using Instat GraphPad software, and student's t-test with the statistical significance set at $\alpha 0.05$ and a confidence interval of $95 \%$. 


\section{Results}

\section{Macroscopical aspects}

The buffalo glands were large and rounded in shape, divided into two lobes (right and left) situated between the rostral colicules (Figure 1a) and possessing a stem with a visible lumen and varying in size, depending upon the animal. The glands were light beige in color, with occasional areas of hyperpigmentation. The weight of the gland varied to the animals from 120 to $400 \mathrm{mg}$ $(251.4 \pm 83.1 \mathrm{mg})$, the width varied from 7 to $9 \mathrm{~mm}(7.9$ $\pm 0.8 \mathrm{~mm})$, and the length varied from 7 to $10 \mathrm{~mm}(8.8$ $\pm 1.0 \mathrm{~mm})$. The stem varied from 2 to $15 \mathrm{~mm}$ in length $(5.5 \pm 4.1 \mathrm{~mm})$. Metabolic weight was calculated and was significantly different, but when the net weight of the animal was compared to the gland weight, there was no significant difference. The general data of the macroscopical study are given in Table 1.

After separation of the animals into 3 groups of weight intervals: Group I (360-459kg), Group II (460-559kg), and Group III (560-600kg), weights were compared and a significant difference was observed (Table 2). However, when the gland weights were expressed as a percentage of the metabolic weights, this difference did not exist. When we compared the gland weights in two photoperiods (short and long) using the t-test, the result was 0.12 , showing no significant difference $(\mathrm{P}>0.05)$. It should be pointed out that the net weight was calculated with a view to minimizing the difference in body weights between the groups (Table 3).

TABLE 1: Number, weight and age of animals; weight, length, width and stem length of the buffalo pineal gland.

\begin{tabular}{|c|c|c|c|c|c|c|c|}
\hline \multicolumn{3}{|c|}{$\begin{array}{l}\text { Number, weight and metabolic weight* of } \\
\text { animals }\end{array}$} & \multirow{2}{*}{$\begin{array}{c}\text { Age of } \\
\text { animal } \\
\text { (months) }\end{array}$} & \multirow{2}{*}{$\begin{array}{c}\text { Gland } \\
\text { weight } \\
\text { (mg) }\end{array}$} & \multirow{2}{*}{$\begin{array}{l}\text { Length of } \\
\text { gland } \\
\text { (mm) }\end{array}$} & \multirow{2}{*}{$\begin{array}{l}\text { Width of } \\
\text { gland } \\
(\mathrm{mm})\end{array}$} & \multirow{2}{*}{$\begin{array}{l}\text { Length of } \\
\text { stem } \\
(\mathbf{m m})\end{array}$} \\
\hline № & $\begin{array}{l}\text { Weight } \\
\text { (kg) }\end{array}$ & $\begin{array}{c}\text { Metabolic weight } \\
\text { (kg) } \\
\text { (Live weight }^{(0.75)} \text { ) }\end{array}$ & & & & & \\
\hline $1 \mathrm{~L}^{\mathrm{a}}$ & 467 & 350 & 21 & 180 & 8 & 7 & 4 \\
\hline $2 L^{n}$ & 500 & 375 & 43 & 210 & 8 & 8 & 3 \\
\hline $3 L^{n}$ & 528 & 396 & 42 & 120 & 7 & 7 & 3 \\
\hline $4 L^{n}$ & 530 & 398 & 41 & 400 & 10 & 9 & 15 \\
\hline $5 \mathrm{~L}^{\mathrm{n}}$ & 560 & 420 & 32 & 252 & 8 & 9 & 12 \\
\hline $6 L^{n}$ & 369 & 277 & 21 & 182 & 10 & 7 & 2 \\
\hline $7 \mathrm{~S}^{\mathrm{j}}$ & 414 & 311 & 23 & 222 & 10 & 8 & 3 \\
\hline $8 \mathrm{~S}^{\mathrm{j}}$ & 403 & 302 & 20 & 272 & 9 & 7 & 4 \\
\hline $9 S^{\text {au }}$ & 600 & 450 & 41 & 288 & 9 & 9 & 4 \\
\hline $10 S^{a u}$ & 660 & 495 & 40 & 265 & 10 & 8 & 4 \\
\hline $11 \mathrm{~S}^{\text {au }}$ & 574 & 430 & 58 & 375 & 8 & 8 & 7 \\
\hline Total & 5605 & 4203 & I & I & I & I & / \\
\hline Mean SD & $509.5 \pm 89.6$ & $382.1 \pm 67.2$ & 1 & $251.4 \pm 83.1$ & $8.8 \pm 1.0$ & $7.9 \pm 0.8$ & $5.5 \pm 4.1$ \\
\hline
\end{tabular}

$\mathrm{L}$ - long photoperiod - spring/summer (more than twelve hours of light $-\mathrm{a}=$ October; $\mathrm{n}=$ November). $\mathrm{S}-$ short photoperiod - autumn/ winter (less than twelve hours of light $-\mathrm{au}=$ August $\mathrm{j}=\mathrm{July}$ ). 
TABLE 2: Comparison of animal weight, separated by intervals, and gland weights.

\begin{tabular}{cccccc}
\hline & Animal weight (kg) & & \multicolumn{3}{c}{ Gland weight (mg) } \\
\hline Group I & Group II & Group IIII & Group I & Group II & Group IIII \\
369 & 467 & 560 & 182 & 180 & 252 \\
414 & 500 & 574 & 222 & 210 & 375 \\
403 & 528 & 600 & 272 & 120 & 288 \\
- & 530 & 660 & - & 400 & 265 \\
$395.3 \pm 23.4^{1}$ & $506.2 \pm 29.5^{2}$ & $598 \pm 44.2^{2}$ & $225.3 \pm 45.0^{3}$ & $227.5 \pm 120.9^{3}$ & $295.0 \pm 55.3^{3}$ \\
\hline
\end{tabular}

x-Equal numbers signify "measured equally within itself". Different numbers signify "different averages within itself".

TABLE 3: Relationship between live weight, metabolic weight, \% pineal gland weight and photoperiod.

\begin{tabular}{|c|c|c|c|c|}
\hline $\mathbf{N}$ & $\begin{array}{c}\text { Weight of animals } \\
\text { (kg) }\end{array}$ & $\begin{array}{c}\text { Metabolic weight of } \\
\text { animals (mg) } \\
\left.\text { (Live weight }^{(0.75)}\right)\end{array}$ & Gland weight (mg) & $\begin{array}{l}\% \text { gland weight in } \\
\text { relation to the } \\
\text { metabolic weight }\end{array}$ \\
\hline $1 \mathrm{~L}^{\mathrm{a}}$ & 467 & 350000 & 180 & 0.05 \\
\hline $2 \mathrm{~L}^{\mathrm{n}}$ & 500 & 375000 & 210 & 0.05 \\
\hline $3 L^{n}$ & 528 & 396000 & 120 & 0.03 \\
\hline $4 L^{n}$ & 530 & 398000 & 400 & 0.10 \\
\hline $5 \mathrm{~L}^{\mathrm{n}}$ & 560 & 420000 & 252 & 0.06 \\
\hline $6 \mathrm{~L}^{\mathrm{n}}$ & 369 & 277000 & 182 & 0.03 \\
\hline MEAN L/SD & $492.33 \pm 62.15^{1}$ & $369333.3 \pm 46603.53^{3}$ & $224 \pm 88.0^{4}$ & $0.05 \pm 0.02^{5}$ \\
\hline $7 \mathrm{~S}^{\mathrm{j}}$ & 414 & 311000 & 222 & 0.07 \\
\hline $8 \mathrm{~S}^{\mathrm{j}}$ & 403 & 302000 & 272 & 0.09 \\
\hline $9 \mathrm{~S}^{\mathrm{au}}$ & 600 & 450000 & 288 & 0.06 \\
\hline $10 S^{a u}$ & 660 & 495000 & 265 & 0.05 \\
\hline $11 \mathrm{~S}^{\text {au }}$ & 574 & 430000 & 375 & 0.08 \\
\hline MEAN S/SD & $530.2 \pm 103,26^{2}$ & $397600 \pm 77357.86^{3}$ & $284.4 \pm 50.28^{4}$ & $0.07 \pm 0.01^{5}$ \\
\hline TOTAL MEAN/SD & $509.5 \pm 89.6$ & l & $251.4 \pm 83.1$ & $0.06 \pm 0.01$ \\
\hline
\end{tabular}

$\mathrm{L}$ - long photoperiod - spring/summer (more than twelve hours of light $-\mathrm{a}=$ October; $\mathrm{n}=$ November).

$\mathrm{S}-$ short photoperiod - autumn/winter (less than twelve hours of light $-\mathrm{au}=$ August; $\mathrm{j}=\mathrm{July}$ ).

\section{Histological aspects}

The gland is covered with a connective tissue capsule that infiltrates the entire parenchyma (Figure 1b). Upon observation of the caudal and rostral regions, differences in the quality of connective tissue are noted (Figure 1b). These differences may be clearly distinguished using specific staining with picrosirius, demonstrating the caudal region as being much richer in collagen fibers. The pineal body possesses innumerous calcium concretions (Figure 1c) situated principally in the central region of the gland. These concretions occur with the same frequency in both animals considered as young and those considered to be older. The glandular parenchyma is composed largely of pinealocytes (Figure 1d), rounded cells with a clear, abundant and acidophilic cytoplasm, and a large round nucleus. The sustentation of these cells is linked to the glial cells present in the area surrounding the pinealocytes. The blood supply of the gland occurs principally via the trabecules of the connective tissue, where the majority of blood vessels 
may be found. A large quantity of the blood vessels may be also be observed in the connective tissue capsule that covers the organ (Figure 1e). The single pineal recess, found in the gland, is covered as depicted in Figure 1f. This recess is covered by a cylindrical epithelium around the lumen of the stem (Figure 1f). Pinealocytes were not found in the region where the stem enters the intertalamic adherence region. Thus, it was evident that the pineal gland of the buffalo did not possess a denominated base or profound region connected to the top of the third ventricle. However, it did possess an apex or pineal body, where functional secretory cells (pinealocytes) were found and a stem that did not possess any secretory cells (pinealocytes), but possessed a lumen that connected to the third ventricle. We may therefore conclude that secretion of melatonin, perhaps, occurs in the cephalic liquid as described by Tricoire et al. (2003).

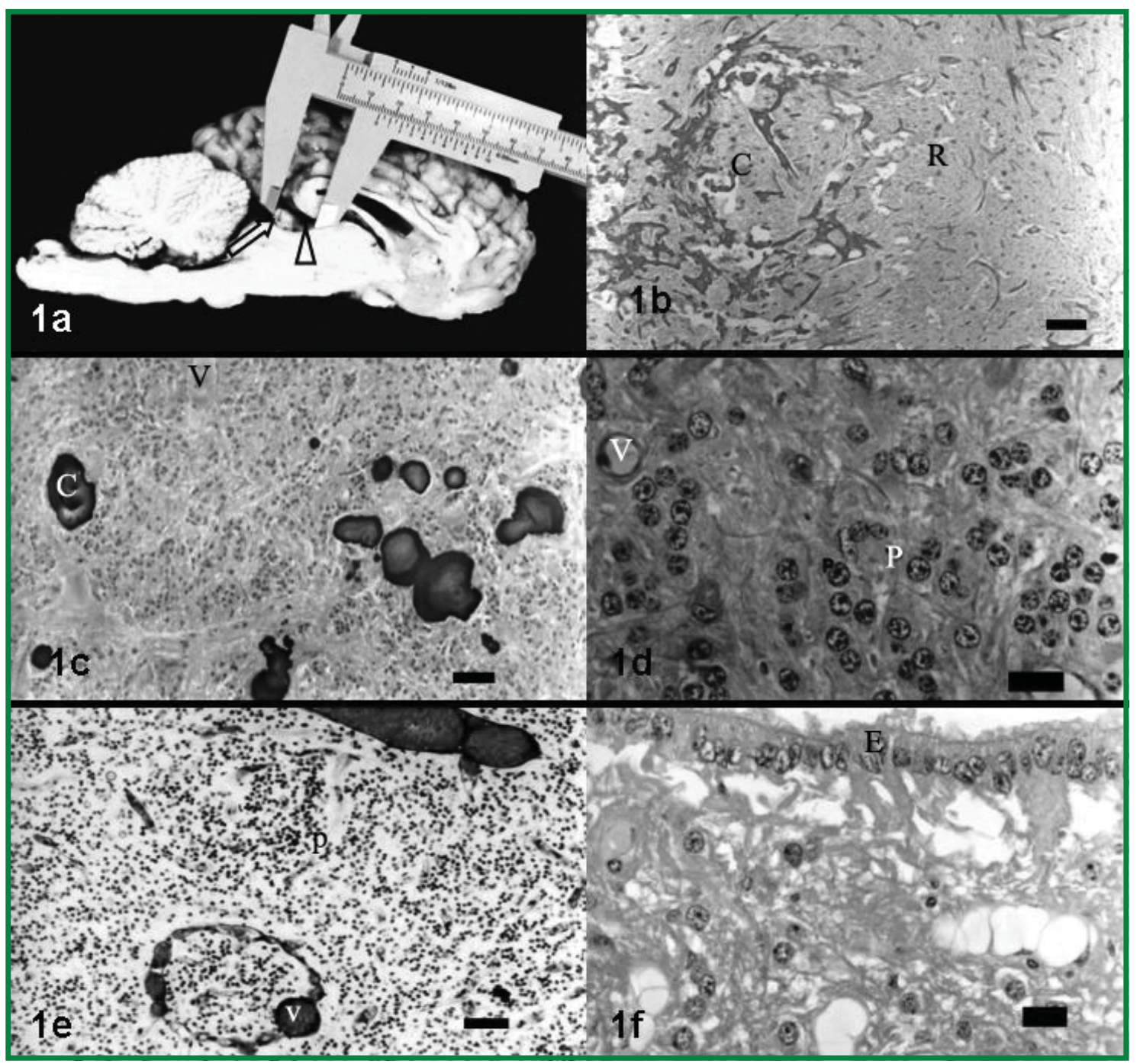

FIGURE 1: 1a Photograph of the brain (Bubalus bubalis) of a male buffalo demonstrating the gland length (mm) in medium sagittal cut (arrow) and stem (head arrow), and its post-callous position. 1b, 1c, 1d, 1e and 1f - Photomicrographs of the buffalo pineal gland: $1 \mathrm{~b}$ - detailing the difference in the quantity of connective tissue (stained dark) between the caudal (c) and rostral (R) regions. Picrosirius. Scale Bar: $220 \mu \mathrm{m}$, historesin embebbed. Figure 1c shows the calcium concretions (c), vessels (V) and connective tissue trabecules (T). HE. Scale Bar: $90 \mu \mathrm{m}$, historesin section. Historesin section of Figure 1d showing the nuclei of the pinealocytes (P) and blood vessels (V). Toluidine blue. Scale Bar: $20 \mu \mathrm{m}$. Historesin section of Figure 1e showing details of the blood vessels (V) and nuclei of the pinealocytes (P). Silver-methanamine periodic acid. Scale Bar: $20 \mu \mathrm{m}$. Historesin section of Figure 1f showing the single recess of the buffalo pineal gland with columnar ciliated epithelium (E). HE. Scale Bar: $220 \mu \mathrm{m}$. 


\section{Discussion}

\section{Anatomy of the pineal gland}

The architecture of the buffalo pineal gland is similar to that described in other mammals. In this study, the gland was seen to have a mean weight of $251.4 \pm$ $83.1 \mathrm{mg}$, whilst Rao and Saigal (1971) reported that the mean gland weight of 6 adult buffaloes in India was $205 \mathrm{mg}$ ( $18.4 \%$ lower than in the present study). The mean length and width of the gland found were $8.8 \pm$ 1.0 and $7.9 \pm 0.8 \mathrm{~mm}$ respectively, while Rao and Saigal (1971) reported 7.1 and 7.0 respectively $(19.5 \%$ and $11.5 \%$ less, respectively, than in the present study). These data may signify a different evolution in these Indian animals to the buffalo studied in our region, although the race of buffalo and photoperiod studied were not specified by the authors. There was no significant difference $(\mathrm{P}>0.05)$ when the weight, length and width were compared.

Dellman and Brow (1982) reported that animals maintained in the dark have a pineal gland of increased size with an increased activity. The animal 04, which possessed the largest gland weight $(400 \mathrm{mg}$ ), was not pregnant, was not the youngest animal (41 months), and had a history of one parturition, demonstrating the animal as being normal and not having suffered any incident that may have caused the weight of its gland to be greater than those of the other animals. This animal was not submitted to continuous darkness, nor was it sacrificed during the long photoperiod, so it was not possible to relate any of these factors to the weight of its gland. Vollrath (1981) reported that there was no correlation between the pineal weight, body weight, cerebral weight, sex or color in man, but that a large variation in the weight exists in the species studied and that the weight tends to decrease with age.

In milk cows, the pineals are seen to be larger than in non-milk producing cows. In this study, the proportionate relationship of the pineal gland weight to the live weight (Table 3 ) of animals is homogeneous between groups (Table 2, P >0.05), although there are significant differences when the live weights of the animals are compared between these groups $(\mathrm{P}<0.05)$. The animal weight, metabolic weight and glandular weight data are compared and shown in Table 3 . The animal with the largest live weight and metabolic weight (number 10) possessed a pineal gland of weight (265mg) close to that of the mean value $(251.4 \pm 83.1 \mathrm{mg})$ presented in this study, confirming the study of Volrath (1979) where the metabolic weight has no influence on the pineal weight.

Sato et al. (1991) further states that the cells present in the habenular commissura possess secretory activity and that the pineal gland of the bovine communicates with the third ventricle. In a similar manner, in buffalos, the gland communicates with the lumen of the stem and the third ventricle. This lumen penetrates the gland forming a single recess. The stem possesses a mean length of $5.5 \pm 4.3 \mathrm{~mm}$. In bovines this stem is absent, demonstrating a great difference between these species (Vollrath, 1979). The anatomic localization of the gland in the brain, found in buffalos, is similar to that described in other mammals by Vollrath (1981). In the buffalo, the pineal gland is found among the rostral colicules in the median fissure of the brain, possessing an insertion in the habenular commissura, which communicates directly with the third ventricles. Arterial irrigation occurs via the pineal network, where the dorsal position of the gland is covered with a tangled vascular complex that penetrates the gland, dividing it, macroscopically, into two lobes, left and right. The macroscopic aspect of the buffalo pineal gland is similar to that of a peanut, including the division of its two sections. An accessory pineal organ was not found in any of the animals studied, contrary to the finding of Prassad and Sinha (1984), where an accessory pineal body was found in a study of 12 animals. Vollrath (1979) classified pineals that were restricted to the vicinity of the third ventricle, and possessed a length similar to that of the width, as type A, demonstrating homology with our findings. Borguese et al. (1995) reported the use of a serial melatonin dosage technique for the study of the secretory activity of melatonin in the buffalo, during the four seasons of the year (spring/ summer and autumn/winter). This work was carried out at the Formancina farm and utilized 16 heifers ( 2 years old) and 16 non-pregnant cows. The farm is situated to the northwest of Rome at latitude 42 degrees, north. The results of this study revealed that buffalos (in Italy) are photosensitive. Significant variations in the secretion of 
melatonin exist depending on the period (season of the year), reproductive stage and age of the animals. In the present study, was carried out at a latitude of $21^{\circ} 56^{\prime} 46^{\prime \prime}$, south (Pirassununga - SP, Brazil), the animals presented reproductive seasonality, although no investigation into the secretion of melatonin (serial dosage) was made to determine the levels secreted during the various times of the year during this study.

\section{Histology}

Cytoplasmic granules were not observed in the buffalo pinealocytes in this study, confirming the findings of Rao and Saigal (1977). The presence of pigments in the pineal gland has been described in man (Bayerova et al., 1962) and in other mammals, such as bovines (Santamarina and Meyer-Arendt, 1956), the rabbit (Romijn, 1973), the hamster (Sheridan and Reiter, 1973), the chinchila (Matsushima and Reiter, 1975 - apud Calvo et al., 1988), the bat (Pevet et al., 1977) and the horse (Cozzi and Ferranti, 1984; Cozzi, 1986). Three classes of pigment may be found in the pineal; melanin, lipofuscin and hemosiderin (Quay, 1956). In some species, melatonin has been identified by immunohistochemical methods (Santamarina et al., 1956; Cozzi and Ferranti, 1984; Calvo et al., 1988). The pigmented cells are constant elements of the pineal gland in adult dogs. The number of pigmented cells is small in comparison to the total number of cells in the pineal parenchyma and many variations may be found in different animals (Calvo et al., 1988). Prasad and Sinha (1984) suggested that, histologically, the pinealocytes are the predominant cells in the buffalo pineal. Comparatively, the buffalo pineal, studied here, possessed pinealocytes that were closely arranged in groups of irregular strings, intermingled with connective tissue. The pinealocytes possess a large nucleus with obvious nucleoli, confirming the findings of Rao and Saigal (1971), and the connective tissue has a large quantity of blood vessels. The gland's capsule, also of connective tissue, possesses an organization rich in subcapsular capillaries with well-defined collagen fibers. The connective tissue penetrates the gland, dividing it into lobes, and it provides enervation and irrigation for the entire parenchyma. There is a distinct difference in the quantity of intraglandular connective tissue in the buffalo, separating the gland into two distinct portions, anterior (rostral) and posterior (caudal), demonstrating that the observations made by Quay (1956) on the pineal organ of rats may also be applied to buffaloes (Figure 1b). Typical ependimary cells are present in the lining of the pineal recess, forming a columnar epithelium in the same manner as described by Rao and Saigal (1971) (Figure 1f). Considering that the oldest animal of this study was 58 months old, we suggest that all the animals may be considered as young animals, although in clear sexual activity and without any indication of senility. The animals of the present study were in the initial phase of sexual maturity or in characteristic sexual maturity, taking into consideration that they had received an alimentary diet of a satisfactory nutritional level and that the puberty phase occurs at approximately 13 months under these conditions. The concretions were evident in all glands, including animals considered to be young (22 months) (Figure 1c). The concretions and tissue losses seen occurred principally in the caudal region of the gland, confirming the data of Hellman and Larsson (1961).

Thus, we conclude that the buffalo pineal gland is similar in gross and microscopic aspects to that of the bovine pineal, type A, and that it does not show any cellular morphologic alterations during different photoperiods of the year.

\section{References}

Ahmed, N.; Chaudhry, R. A.; Khan, B. B. 1981. Effect of month of season of calving on the length of subsequent calving interval in Nili - Ravi buffaloes. Animal Reproduction Science, 3: 301.

Bayerova, G.; Bayer, A.; Obrucnik, M. 1962. Zur Frage der fluorescenz - und polarisations- mikroskopieschen Untersuchungen an der menschlichen Epiphyse. 1962. Acta Histochem, 14: 276283.

Borguese, A.;. Barile, V.; Terezano, G. M.; Pilla, A. M. A. 1995. Parmeggiani. Melatonin trend during seasons in heifers and buffalo cows: Andamento della melatonina emática nelle 4 stagione in manze e bufale adulte. Journal of Buffalo Science and Technique, 1 (1): 61-65.

Calvo, J.; Boya, J.; Garcia-Mauriño, J. E.; Carbonell, L. 1988. Structure and ultrastructure of the pigmented cells in the adult dog pineal gland. Journal of Anatomy, 160: 67-73.

Cozzi, B. 1986. Cell types in the pineal gland of the horse: an ultrastructural and immunocytochemical study. Anatomical Record, 216: 165-174. 
Cozzi, B.; Ferranti, B. 1984. Fine structure and histochemistry of the equine pineal gland, with special reference to the possible functional role of the electrodense intrapinealocyte bodies. Clínica Veterinária, 107: 337-346.

Dellman, H. -D.; Brow, M. E. 1982. Histologia Veterinária. Guanabara Koogan, Rio de Janeiro, Brasil, 398pp.

Gerrits, P. O. 1983. Staining procedures for tissues embedded in 2-hydroxyetry methracrylate. Mikroskopie, 5: 321-328.

Hafez, E. S. E. 1995. Reprodução animal. $6^{\text {a }}$ ed. Manole, São Paulo, Brasil, 582pp.

Hellman, B.; Larsson, S. 1961. Utilization of uniformly labelled C-14 glucose in the pineal body of the goat. Acta Endocrinologica, 38: $353-360$.

Junqueira, L. C. V.; Bignonas, G.; Bretan, R. P. 1979. Picrosirius staining plus polarization microscopy, a specific method for collagen detection in the tissue sections. Histochem Journal, 11: 447-455.

Kaker, M. L.; Razdan, M. N.; Galhotra, M. M. 1982. Serum prolactin levels of non-cycling Murrah buffaloes (Bubalus bubalis). Theriogenology, 17: 469.

Lillie, R. D.; Fulmer, H. M. 1976. Histopathologic Technique and Practical Histochemistry. $4^{\text {nd }}$ ed. MacGraw-Hill, New York, USA, 942pp.

McDowell, E.; Trump, B. F. 1976. Histological fixatives suitable for diagnostic light and electron microscopy. Archives of Pathology, 100: 405-413.

Pevet, P.; Kappers, J. A.; Voute, A. M. 1988. The pineal gland of nocturnal mammals. In: The pinealocytes of the bat (Nyctalus noctula, Schreber). Journal of Neural Transmission, 40: 47-68.

Prassad, J.; Sinha, R. D. 1984. Histological and histochemical studies on the pineal and accessory pineal bodies in bufallo. Indian Journal Animal Science, 54 (1): 45-49.

Quay, W. B. 1956. Volumetric and cytologic variation in the pineal body of Peromyces leucopus (Rodendia) with respect to sex, captivity and day length. Journal of Morphology, 98: 471-496.

Rao, L. V.; Pandey, R. S. 1982. Seasonal changes in plasma progesterone concentrations in buffalo cows (Bubalus bubalis). Journal Reproduction and Fertility, 66: 57.
Rao, G. S.; Saigal, R. P. A. 1971. Quantitative morphological study of pineal organ in the buffalo. Indian Journal Animal Science, 41: 438-443.

Regodón, S.; Roncero,V. 2005. Embryonic development of the pineal gland (Bos Taurus) during prenatal life (30-135 days of gestation). Histology and histopathology, 4: 1093-1103.

Regodón, S.; Pozo, D.; Roncero, V. 2006. Histomorphogenesis and immunohistochemical study of the bovine pineal gland (Bos Taurus) during prenatal development (160 days of gestation to birth). Histology and Histophatology, 10 (21): 1043-1053.

Romijn, H. J. 1973. Structure and innervation of the pineal gland of the rabbit, Oryctulagus cuniculus (L.). II. An electron microscopic investigation of the pinealocytes. Zeitschrft für Zellforschung und Mikroskopischen Anatomie, 141: 545-560.

Santamarina, E.; Meyer-Arendt, J. 1956. Identification of melanin in the bovine pineal gland. Acta Histochemica, 3: 1-5.

Sato, T.; Deguchi, T.; Ichikawa, T.; Fujieda, H. 1991. Localization of hydroxyndole-o-methyltransferase synthesizing cells in bovine epithalamus: immunocytochemistry and in-situ hybridization. Cell Tissue Research, 263: 413-418.

Schomerus, C.; Korf, H. W. 2005. Mechanisms regulating melatonin synthesis in the mammalian pineal organ. Annals of the New York Academy of Sciences, 1057: 372-383.

Sheridan, M. N.; Reiter, R. J. 1973. The fine structure of the pineal gland of Pocket Gopher, Geomys bursarius. American Journal of Anatomy, 136: 363-382.

Tolosa, E. M. C.; Rodrigues, C. J.; Behmer, O. A.; Freitas-Neto, A. G. 2003. Manual de Técnicas para Histologia Normal e Patológica. $2^{\mathrm{a}}$ ed. Manole, São Paulo, Brasil, 331pp.

Tricoire, H.; Moller, M.; Chemineau, P.; Malpaux, B. 2003. Origin of cerebrospinal fluid melatonin and possible function in the integration of photoperiod. Reproduction Supll, 61: 311-321.

Vollrath, L. 1979. Comparative morphology of the vertebrate pineal complex. The pineal gland including man. Progress in Brain Research, 42: 25-38.

Vollrath, L. 1981. The pineal organ. $1^{\text {st }}$ ed. Springer Verlag Berlin Heidelberg, New York, USA, 942pp. 